
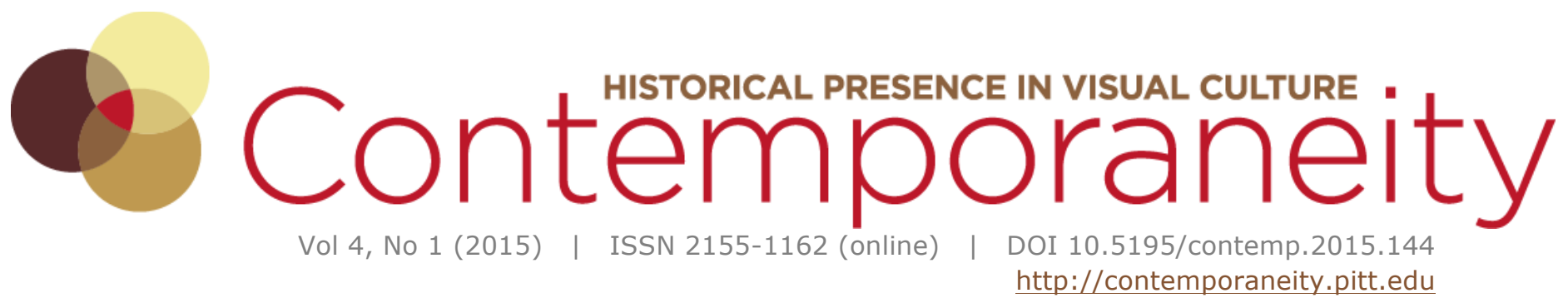

\title{
Spinifex People as Cold War Moderns
}

\author{
Greg Castillo
}

\begin{abstract}
Aboriginal Australian contemporary artists create works that express indigenous traditions as well as the unprecedented conditions of global modernity. This is especially true for the founders of the Spinifex Arts Project, a collective established in 1997 to create so-called "government paintings": the large-scale canvases produced as documents of land tenure used in negotiations with the government of Western Australia to reclaim expropriated desert homelands. British and Australian nuclear testing in the 1950s displaced the Anangu juta pila nguru, now known to us as the Spinifex people, from their nomadic lifeworld. Exodus and the subsequent struggle to regain lost homelands through paintings created as corroborating evidence for native title claims make Spinifex canvases not simply expressions of Tjukurpa, or "Dreamings," but also artifacts of the atomic age and its impact on a culture seemingly far from the front lines of cold war conflict.
\end{abstract}

\section{About the Author}

Greg Castillo, an architectural and design historian, is an Associate Professor at the College of Environmental Design at the University of California, Berkley, and a Research Associate at the United States Studies Centre at the University of Sydney, Australia. His work has focused on design politics in the early cold war era and the counterculture moment of the late '60s and early '70s. He has delivered public lectures at the New York Museum of Modern Art, London's Victoria and Albert Museum, the National Gallery of Denmark and universities internationally. He is the author of numerous articles, anthology chapters, and the monograph Cold War on the Home Front: The Soft Power of Midcentury Design (2010). 


\section{Spinifex People as Cold War Moderns}

In early October 1986, a desert-dwelling family of a community known as the Anagu tjuta pila nguru, or "people from the land of the spinifex" became the last Aboriginal Australians to abandon traditional nomadic life. ${ }^{1}$ A male elder who had escaped from the Warburton mission with his young wife and stepdaughter twenty-five years earlier headed the family of seven. ${ }^{2}$ Returning to

Greg Castillo the red-earth landscape of spinifex grass and mulga, they raised their children, remaining in the wilderness as family and friends departed for mission life. The family walked from rock hole to rock hole spearing kangaroo, emu, goanna, blue-tongued lizard and mallee hen: the last of five hundred generations to pursue this nomadic way of life across a stretch of remote country now stripped of all other residents. Seeing the glint and streaks of aircraft in desert sky, they threw magical objects at them and sang protective songs. White people were ghosts traveling above them and across the land. They found clothes and pieces of metal left behind by desert visitors, studied tire track imprints, and carefully obscured their own tracks to avoid detection. The couple told their children that distant trains were roaring Wati Wanampi, venomous water-snake beings. From a hill overlooking the Blackstone mission settlement (today, Papulankutja) the children witnessed what they believed was a pitched battle between legendary warmala or warriors. The frightening vista was of an amateur football skirmish. ${ }^{3}$ It would be the family's closest brush with the outside world until 1986.

Exiles living at the Coonana settlement for those displaced by the Maralinga nuclear tests of the 1950s believed their lost desert relatives dead. They were called Kunmanara rather than by name, as required by Aboriginal law. Stories about the family's survival continued to circulate, however, fueled by intermittent sightings of tracks and abandoned

\footnotetext{
1 "After the desert, an Aboriginal faces the 20th century-and is frightened," Sydney Morning Herald, October 14, $1986,3$. Protected by their relatives from contact by reporters and anthropologists, the family of seven largely have been forgotten as the last Aboriginal Australians to abandon nomadic life: a distinction usually given to the so-called "Pintupi nine" retrieved from the desert in 1984, whom the Australian Broadcasting Corporation celebrated thirty years later as "the last remaining group of indigenous Australians to make contact with white Australia" See Alan Mahony, "Pintupi Nine mark 30th anniversary of first contact with white Australia," $A B C$ News, November 4, 2014, accessed February 5, 2015, http://www.abc.net.au/news/2014-10-24/pintupi-mark-anniversary-of-contact-with-white-australia/5840812. See also Richard Guilliatt, "Whatever happened to the Pintupi nine?" The Australian, October 25, 2014. The self-designation "Spinifex people" reflects the precedence of land-tenure identity over language-based classification systems favored by earlier anthropologists. Scott Cane, Pila Nguru: The Spinifex People (Fremantle: Fremantle Arts Centre Press, 2002), 189-190; 6063. For a summary history of Western Desert first contacts, see: Philip Batty, ed., Colliding Worlds: First Contact in the Western Desert 1932-1984 (Melbourne: Museum Victoria, 2006).

${ }^{2}$ Initial newspaper reports about the family mistakenly identified the clan's male elder as the only member of the group to have had previous contact with Euro-Australian society, a fact corrected in a subsequent account, "The 'lost tribe' was right at home," Sydney Morning Herald 10 November 1986, 6. Newspaper accounts variously estimated the family's desert stay at twenty-five to thirty-five years, and Glen Rictor as sixty to seventy years old. Ethnographer Scott Cane's version of events states that Glen Rictor left the Warburton mission with his wife and her daughter from another partnership. Estimates on the amount of time the family spent in the desert range from twenty-five to thirty-five years, depending on the news source. Remarkably, no ethnographic study was ever done documenting the experience of this last Aboriginal family to abandon pre-contact traditions of nomadic life.

3 "The 'lost tribe' was right at home"; "'Lost tribe' now faces threat of white man's diseases," The Age, October 14, 1986, 3; Cane, Pila Nguru, 198, 188-89.
} 
wiltja (windbreaks) across a two hundred kilometer expanse of the Great Victoria Desert. In 1967, one of Coonana's expert trackers, Jerome Anderson, found footprints in the Spinifex homeland that might have been those of the desert family. Nearly twenty years later, a group from Coonana set off in vehicles for a ceremonial visit to native land. They discovered fresh footprints and followed the trail for two days. ${ }^{4}$ One member of the party, Fred Grant, set off on foot one morning before dawn, using a torch of burning wood to light his way (Fig. 1). Hours later, he sighted the family. Encamped in a wiltja, carrying wooden spears and implements, they were still painted with red, yellow and white ochre in preparation for the ritual reburial of a deceased relative. ${ }^{5}$ The three brothers fled. Their adult half-sister approached, speaking an archaic dialect uninflected by the mixing of indigenous languages produced by life at resettlement missions. ${ }^{6}$ "They spoke really quickly, like a bird twittering," recalled Ian Baird, a white Aboriginal Studies graduate from Adelaide who accompanied the expedition and would become the community's coordinator. "When they moved it was like they were moonwalking. ${ }^{7}$ That night, the search party made camp and clothed the people they had once called Kunmanara. Reunited with kin, the husband and wife recognized relatives among the searchers. The male elder wept quietly upon hearing news of people he had not seen in decades.

The newly extended clan set off the next morning. As the four-wheel drive lurched across rough terrain, the male elder became distressed and carsick. When the vehicle bogged down in sand, he leapt out and stripped off his newly acquired clothes. He was going home, and he ordered his kin not to follow. In the ensuing commotion he punished his stepdaughter, the first of his nomadic clan to speak to the strangers, by spearing her in the leg, and walked back into the desert. While his three oldest sons, aided by members of the search party, set off to find their father, the two women and the youngest boy were taken to Coonana. Within days the family was reunited at the mission. The former nomads took a new surname, Rictor, based on that given to kin by missionaries. The brothers became Ian, Mick and Willy; their parents, Glen and Dulcie Rictor; the stepdaughter, Angelina; and her son, Damian. These Euro-Australian designations mediated the family's contact with the outside world, with Pitjatjantjara names now reserved for use by friends and kin. As news of the "lost tribe" spread, the community banned visits by reporters and eager anthropologists. It safeguarded members of the desert family at Yakudunya, a remote outstation, to protect them from contact trauma and the threat of communicable diseases. Angelina, today known as Tjaruwa, instead chose to take Damian north to begin a new life with relatives at Blackstone (Fig. 2). ${ }^{8}$

\footnotetext{
${ }^{4}$ Cane, Pila Nguru, 197-98. In 1983, while Spinifex people were living at Cundeelee, an earlier settlement for those displaced by the Maralinga tests, an anthropologist brought a group of elders back to their ancestral lands for the first time in a generation, a trip that apparently catalyzed a renewed determination to resume custodial obligations. "Elders blaze a trail back to Yakudunya," Sydney Morning Herald, November 10, 1987, 6.

${ }^{5}$ Cane, Pila Nguru, 188-90

6 "Lost tribe walks into the world of 'white ghosts,"' The Courier Mail, October 13, 1987, 3; Cane, Pila Nguru, 63.

${ }^{7}$ Ian Baird, quoted in Chester Quentin, "The Spinifex People," Australian Geographic 116 (Sept./Oct. 2013 ): 90.

8 "The 'lost tribe' was right at home," 6. I am grateful to Amanda Dent and Ian Baird for correcting the inaccuracies embedded within newspaper reports of the 1980s. Today, Angelina paints under the name Tjaruwa Woods; Ian Rictor and Nolie (or Noley) Rictor are also painters.
} 


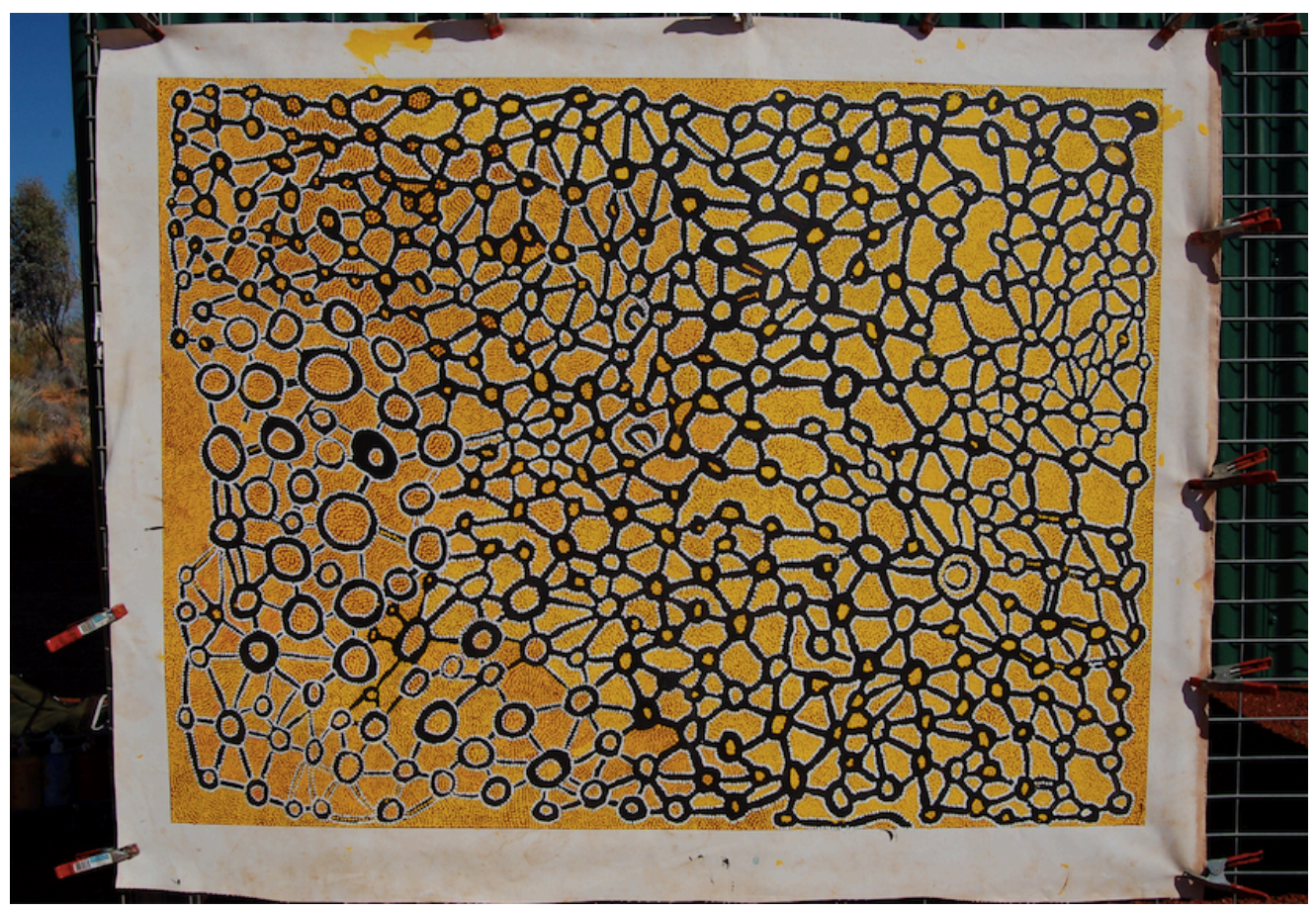

Figure 1

Fred Grant and Carlene West, Ukatjatjara, 2006. Acrylic on linen, $183 \times 137 \mathrm{~cm}$. Private collection (photo: courtesy Spinifex Arts Project).

Grant and West worked together as husband and wife on this depiction of a northern section of Spinifex country where Grant grew up. The painting spans a large area of soaks and rockhole formations; major sites noted are Ukatjatjara, Tjutjala, Pirapi, Miramratjara, Karnka, Urtjul, Yaltapii, Tjitjjiti, Puyuu, Pinkatjara, Muti-Muti, and Muntamatja. A tjitji (young boy) is shown camping near Muti-Muti.

Over the course of a year, media reports about the Rictors percolated out of Western Australia. A barrage of time-worn tropes depicted the family as "the lost people," "the forgotten nomads," and "the last desert tribe." The Sydney Morning Herald reported: "the three sons, the younger woman and her little boy had never seen the modern world before." ${ }^{\prime \prime}$ Newspaper readers remained blissfully ignorant of a facet of modernity to which the "last hunter-gatherers on earth" had been, quite literally, exposed. A thundering shudder Glen Rictor had felt while in the wilderness was that of a nuclear weapons test. He had hidden by digging a hole, climbing in, and covering himself with sand for protection. The same newspaper report noted that Roy Underwood and Simon Hogan, men who would become major Spinifex painters a decade later, had also witnessed atomic tests at Maralinga (Fig. 3). ${ }^{10}$ At the 1984 Royal Commission into British Nuclear Tests in Australia, Carlene West and

\footnotetext{
${ }^{9}$ Ibid.

${ }^{10}$ Cane, Pila Nguru, 198, 189; "After the desert, an Aboriginal faces the $20^{\text {th }}$ century - and is frightened," 3; "Elders blaze a trail back to Yakudunya," 6.
} 
Myrtle Pennington testified that they had heard explosions, felt the earth tremble, and seen strange clouds that had "destroyed" sacred sites (Fig. 4). Given the revelations of the Royal Commission, which established that the boundaries of the nuclear test zone had never been secure, and that by 1960 authorities had accepted the fact that indigenous people were traversing the western edge of the prohibited area, these Aboriginal women and men were by no means alone in having experienced a technological breakthrough that the vast majority of Australians knew only from the safe distance of media abstractions. ${ }^{11}$ Far from having "experienced modern living for the first time in twenty five years" at the time of his retrieval, Glen Rictor, as it turned out, was part of an avant-garde. Cast as a human subject in an uncontrolled experiment in nuclear technology and displaced from his homelands by its radioactive contaminants, "old man" Rictor and his Spinifex kin were custodians of an ancient culture and, simultaneously, cold war moderns.

It is impossible to know just what characterized cold war subjectivity for Spinifex people. "Modernity" and "cold war" are exogenous constructs, forged to give meaning to a vortex of historical events unleashed in places far from Australia's Western Desert, but which upended the lives of Aboriginal nomads. Like the subjects of the Chernobyl catastrophe studied by anthropologist Adriana Petryna, Spinifex people forged new individual and collective identities from their experience of displacement from "poisoned" lands, struggled with insecurity and a sense of injustice, and constructed from these realities new modes of citizenship and, eventually, novel covenants with government. ${ }^{12}$ The Spinifex people's cold war diaspora became a matter of legal record in their native title claim. It was memorialized in the theatre production Career Highlights of the Mamu, which toured Australia and took elder Roy Underwood and eight other Spinifex people to Hamburg in 2002 for the play's international debut (Fig. 4). In the apt words of a theater critic, "fission fused the Spinifex folk."13

As an American historian of cold war culture, I can only chronicle events associated with this indigenous contact with modernity, not the subjective responses it engendered. In any case, my goal lies elsewhere. This essay provides a context for understanding Spinifex painting as what curator Philip Batty has called "intercultural debris": products of a collision of lifeworlds (Fig. 5). ${ }^{14}$ Spinifex canvases-ranging from "government paintings," as the artists call collective works created as documents of land tenure for Native Title Tribunal proceedings (Fig. 6), to works that have graced gallery walls in Australia, Europe and America-breathe life into endangered cultural traditions and convey their existence to inhabitants of an alternate reality that, time and again, has revealed its enormous power and capacity for indifference. Within that realm, Aboriginal cultural artifacts can be stripped of their complex origins, transformed into commodities, and circulated in market transactions between galleries and collectors. This essay is an intervention into that process. It is an attempt to inscribe into Spinifex paintings a set of potent "Dreamings"-not those of the Aboriginal artists, but of a cold war society bent on mastering the dark arts of thermonuclear annihilation, no matter what the cost, in an illusive quest for security. The double entendre

\footnotetext{
11 Tom Gara, "Walter MacDougall and the Emu and Maralinga Nuclear Tests," (undated conference paper), accessed 27 April 2009, www.history.sa.gov.au/history/conference/Tom_Gara2.pdf.

12 Adriana Petryna, Life Exposed: Biological Citizens after Chernobyl (Princeton: Princeton University Press, 2002).

13 Ron Banks, "How fission fused the Spinifex folk," The West Australian (13 May 2002).

14 Philip Batty, "Intercultural Debris," in Philip Batty, ed., Colliding Worlds First Contact in the Western Desert 1932-1984 (Melbourne: Museum Victoria, 2006), 2.
} 
nested in the title of the 2015 British Museum blockbuster Aboriginal Australia: Enduring Civilization-an exhibition featuring works by Ned Grant, Kunmanara (Anne Ngantiri) Hogan, Estelle Hogan, Simon Hogan, Myrtle Pennington, Ian Rictor, Ngalpingka Simms, Yarangka Thomas, Roy Underwood, Lennard Walker, and Tjaruwa Woods-conveys the perplexing nature of our relationship as cultural contemporaries. With the exception of a set of historically significant works in the Spinifex Arts Community Collection, the artists' entire production has left the desert destined for accession in private and institutional collections. Just as Spinifex people reclaimed responsibility for the custodianship of their desert homelands, custodianship of their artistic output is passed to those who purchase it, whether as impassioned collector, enlightened curator, or calculating investor. What follows is a narrative of events that entangle recent Western history with that of the Spinifex people. It is knowledge that can-and I believe should-transform our perception of the works of art entrusted to our care, and which serve as implicit memento mori of the cold war era.

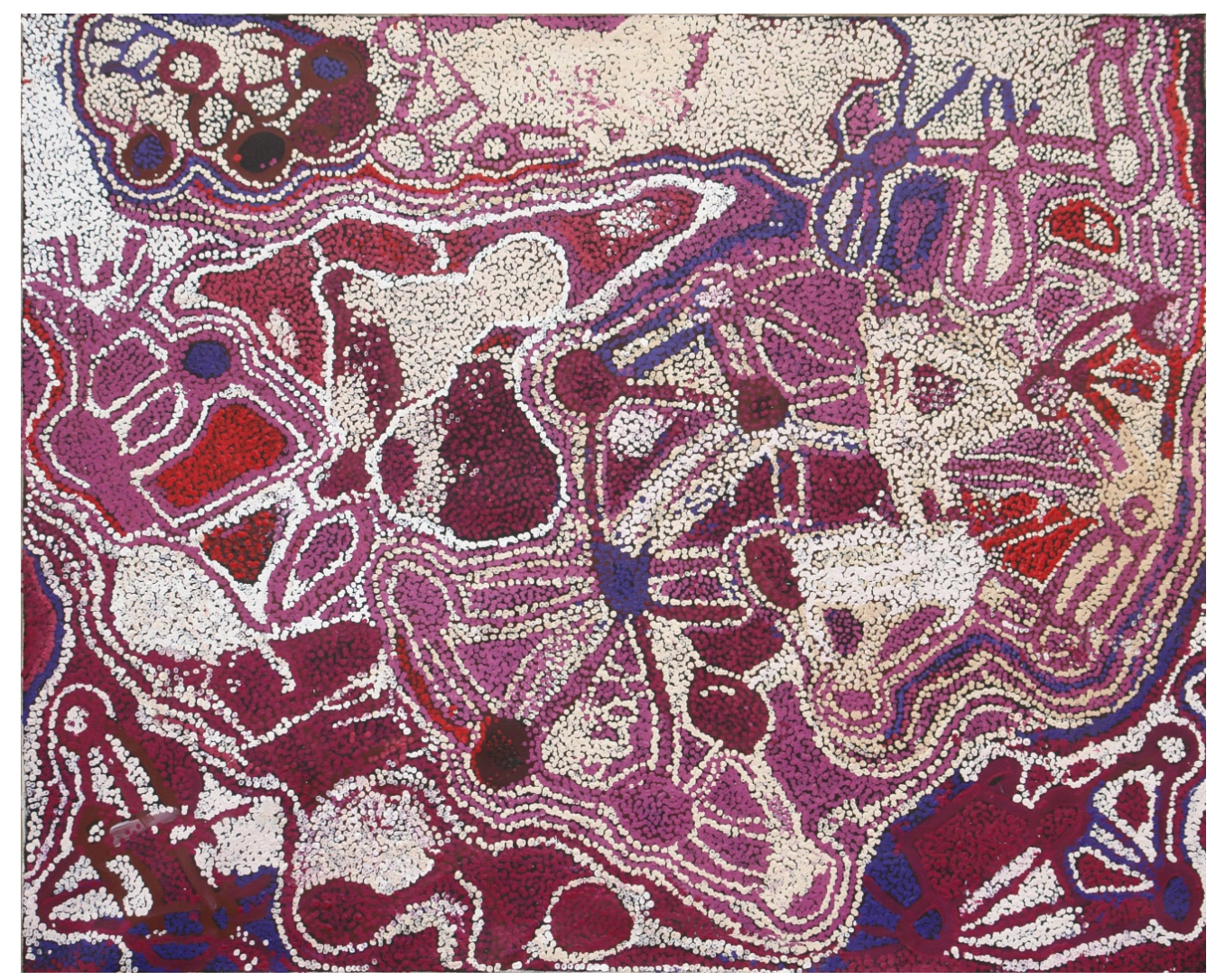

\section{Figure 2}

Tjaruwa Woods, Kamanti, 2009. Acrylic on canvas, 109 × $135.5 \mathrm{~cm}$. The Lepley Collection (photo: courtesy Spinifex Arts Project).

When she was a baby, the artist lived at Kamanti. With its twin rockholes, Kamanti has a double catchment of the water essential to survival under extremely harsh conditions. The Wati Kutjara (Lizard Men) songline, sometimes referred to as "Two Men Dreaming," runs through Kamanti, making it an important site for Tjukurpa. This painting, a dynamic virtual map of country, references many geographic sites bearing the presence of the Tjukurpa fundamental to an understanding of country in its spiritual sense. 


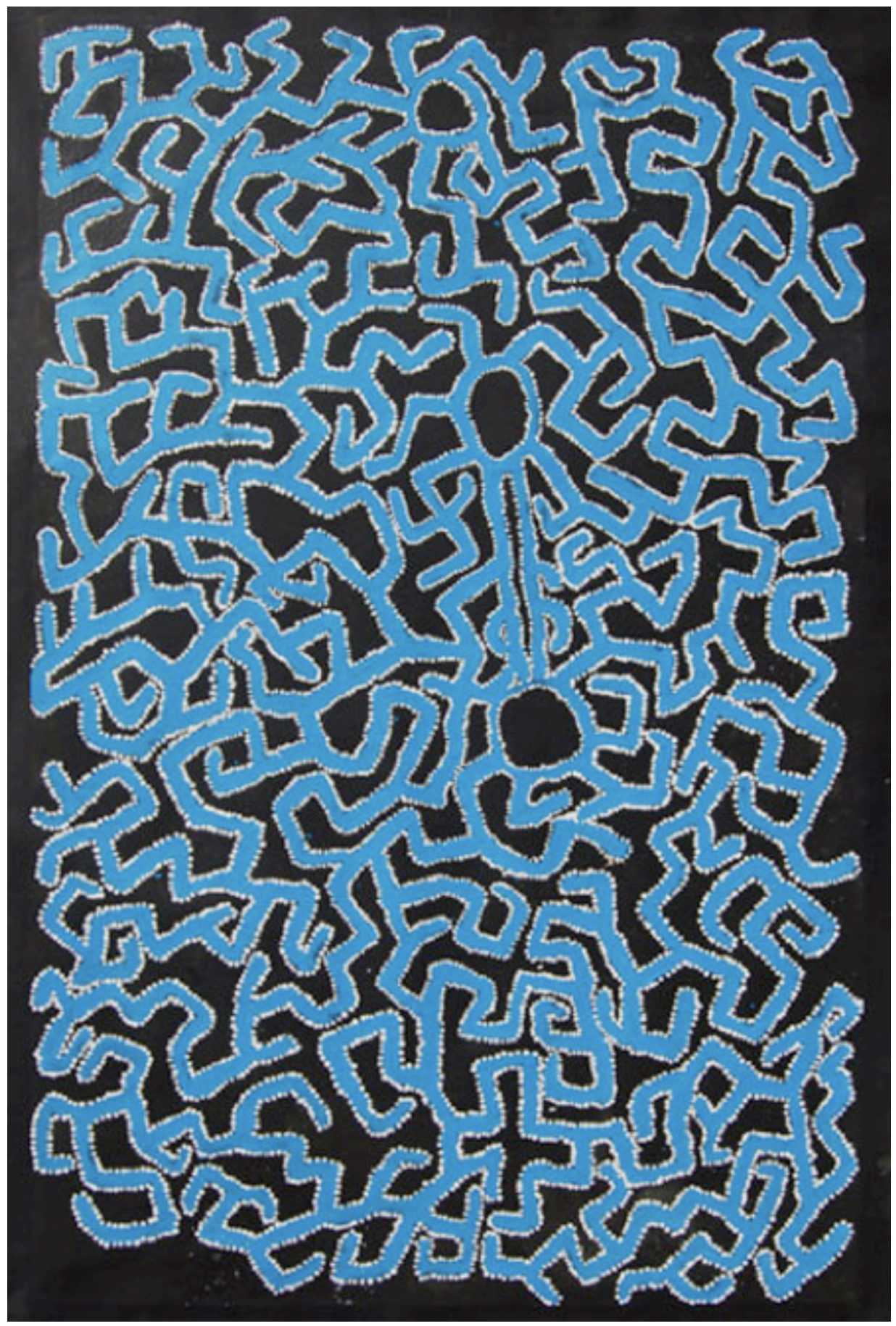

Figure 3

Roy Underwood, Marutjinya, 2006. Acrylic on linen, $105 \times 161 \mathrm{~cm}$. Private collection (photo: courtesy Spinifex Arts Project).

The area of country described in this painting corresponds to Underwood's birthplace. Four major sites are depicted: Kalapi, Marutjinya, Tjutatjara, and Mirukurtja: all surrounded by sandhills that are miil-miilpa (dangerously sacred). Water in these sandhills is protected by a particularly powerful presence that can only be named or spoken about among senior, initiated, Spinifex men. 


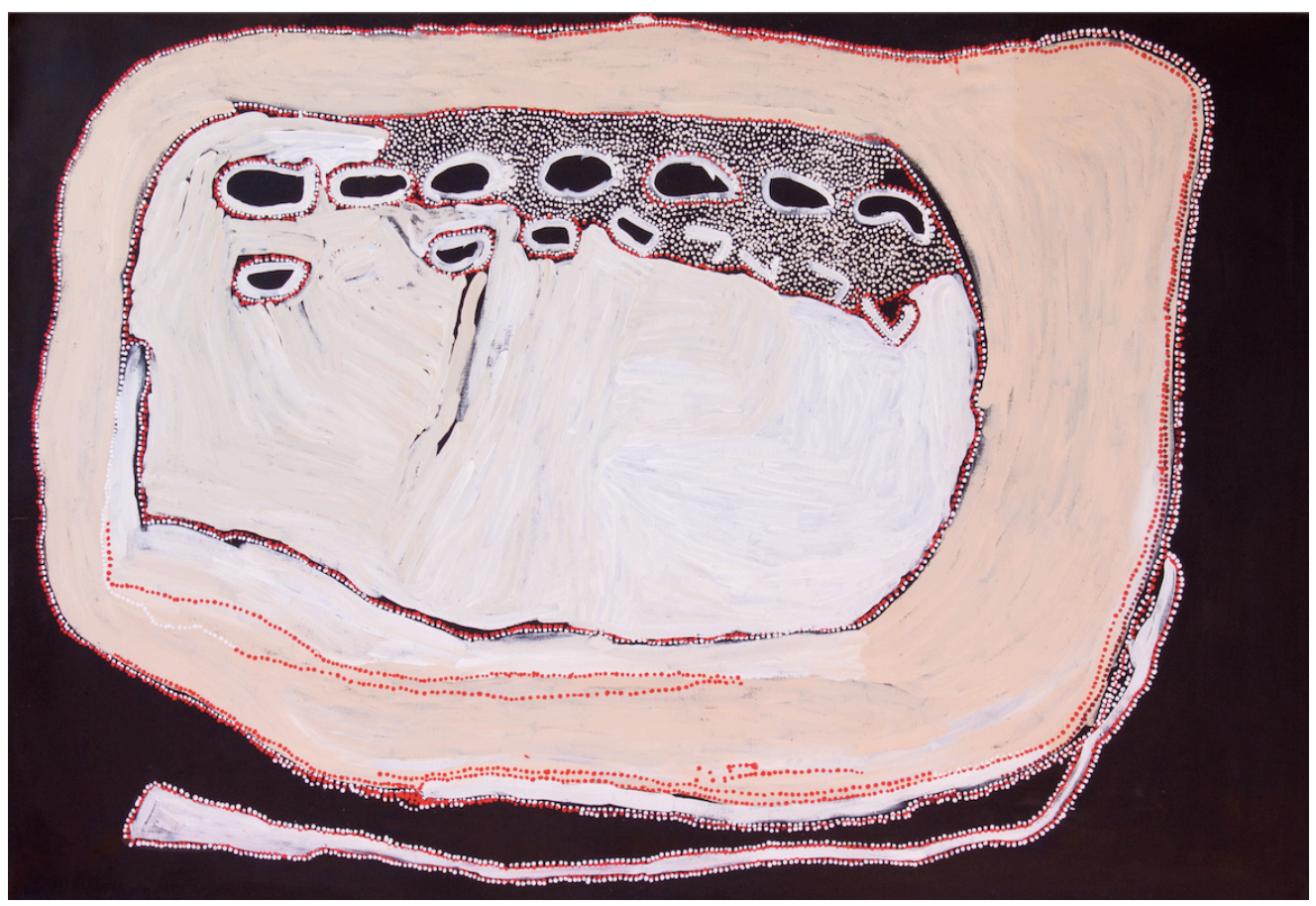

\section{Figure 4}

Carlene West, Tjitjjiti, 2014, acrylic on linen, 200 x 137 cm. Private collection (photo: courtesy Spinifex Arts Project).

From West's account: "This painting represents Tjitjjiti, a large salt lake. It is the site of the creation story of Two Women. This story involves Two Women walking across the big salt lake with a child. A stranger hails them, a Quoll (a marsupial species) Man, who tells them to hand over the child. The ladies ran, but the Quoll Man threw a spear that impaled the Two Women together with the child. This is a sad story. Today those Two Women can still be seen standing at Tjitjjiti."

\section{A Home of Many Hearths}

Invariably, humans produce debris, intercultural or otherwise. Residue scattered around waterholes in the Great Victoria Desert attests to long-term occupation of a landscape considered uninhabitable by non-Aboriginal Australians. Discarded artifacts fanning out several kilometers from water sources pepper the ground at a density of up to seven hundred pieces per square meter. A single site can contain as many as five hundred million fragments, according to anthropologist Scott Cane. To account for this density of debris, "fifty people would have to make and discard at least one hundred thousand artifacts a year over a ten thousand year period." ${ }^{15}$ In fact, evidence suggests occupation of the Spinifex homelands for the last forty thousand years, its pattern of habitation varying with shifts in climate. Groups of nomads foraged within a radius of about twenty kilometers from permanent waterholes. Temporary encampments punctuated the roving course of hunting

${ }^{15}$ Cane, Pila Nguru, 163. 
and food gathering. Longer treks across drier landscapes moved from rock hole to rock hole to collect ochres and valuable raw materials or to visit ritual sites like those distributed through the expanse that in 1947 would become the "prohibited area" of the Woomera Rocket Range. Scouting locations for radiation-detecting sensors, a group of surveyors stumbled across one such totemic site in 1952, east of the Spinifex homelands. Range Reconnaissance Officer Len Beadell dubbed the find a "mysterious Aboriginal 'Stonehenge.'" Geometric arrangements of upended shale slabs stretching for sixty meters prompted him to photograph the stones "from every angle" and collect charcoal samples for carbon dating. In his memoirs, Beadell wrote:

There was an ironic clash of old and new here, as only a few short miles away the first mighty atomic bomb ever to be brought to the mainland of Australia was to be blasted into immediate oblivion in several weeks' time, and it was the by-products of this very weapon which could be used for determining the age of the charcoal from these prehistoric fires.... I couldn't help asking myself what these people, had they still been here, would have imagined if they had witnessed the glow from our atomic upheaval followed by earth tremors and shock waves. ${ }^{16}$

Beadell's presumption that the Aboriginal debris was "prehistoric" reflected a Euro-Australian conviction that the Woomera range was long unoccupied, accounting as well for his matterof-fact attitude regarding the radioactive particles that were about to be strewn across the land.

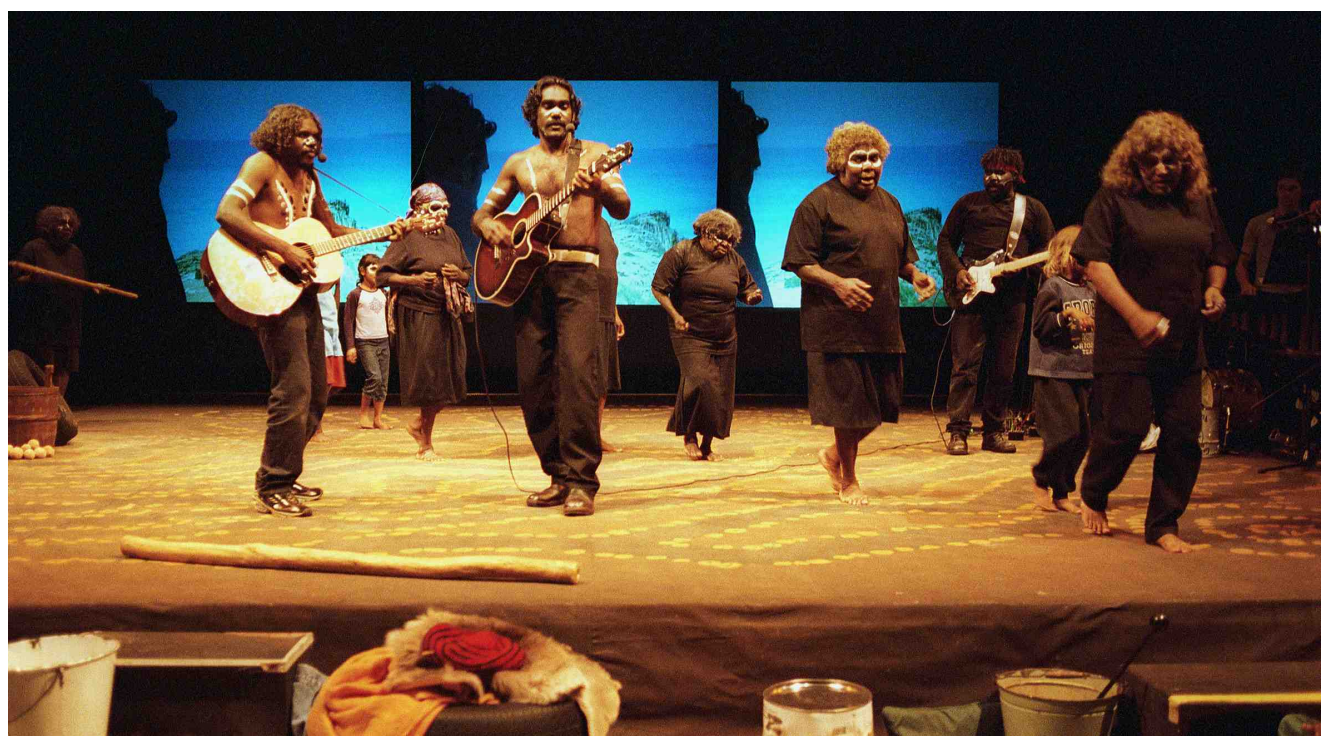

Figure 5

Spinifex community members with Trevor Jamieson in a performance of Career Highlights of the Mamu at the Adelaide Festival, 2002 (photo: courtesy Black Swan Theater Company).

${ }^{16}$ Len Beadell, Blast the Bush (Willoughby: Weldon, 1967), 172-176. 
As with their archaeological past, the Spinifex people's postwar fate can be interpreted from debris. Weapons-grade plutonium is one of the most toxic substances on earth. A speck the size of the period at the end of this sentence, if inhaled, will cause cancer. The Vixen "safety assessment tests" of 1959, two of approximately seven hundred "minor trials" conducted in secret between 1952 and 1963, involved setting plutonium ablaze in a simulated aircraft crash. Another trial, code named Taranaki, released a plume of plutonium detected in soil sampled more than thirty kilometers from the testing grounds. Remediation entailed plowing contaminants into the surface and covering them with a thin layer of soil likely to be blown away by desert winds. ${ }^{17}$ Plutonium has a half-life of twenty-four thousand years, meaning that in forty thousand years - the total duration of Aboriginal land tenure in Australia-plutonium dispersed within the Woomera range (and, perhaps, beyond it) will retain more than one-quarter of its fatal radioactivity.

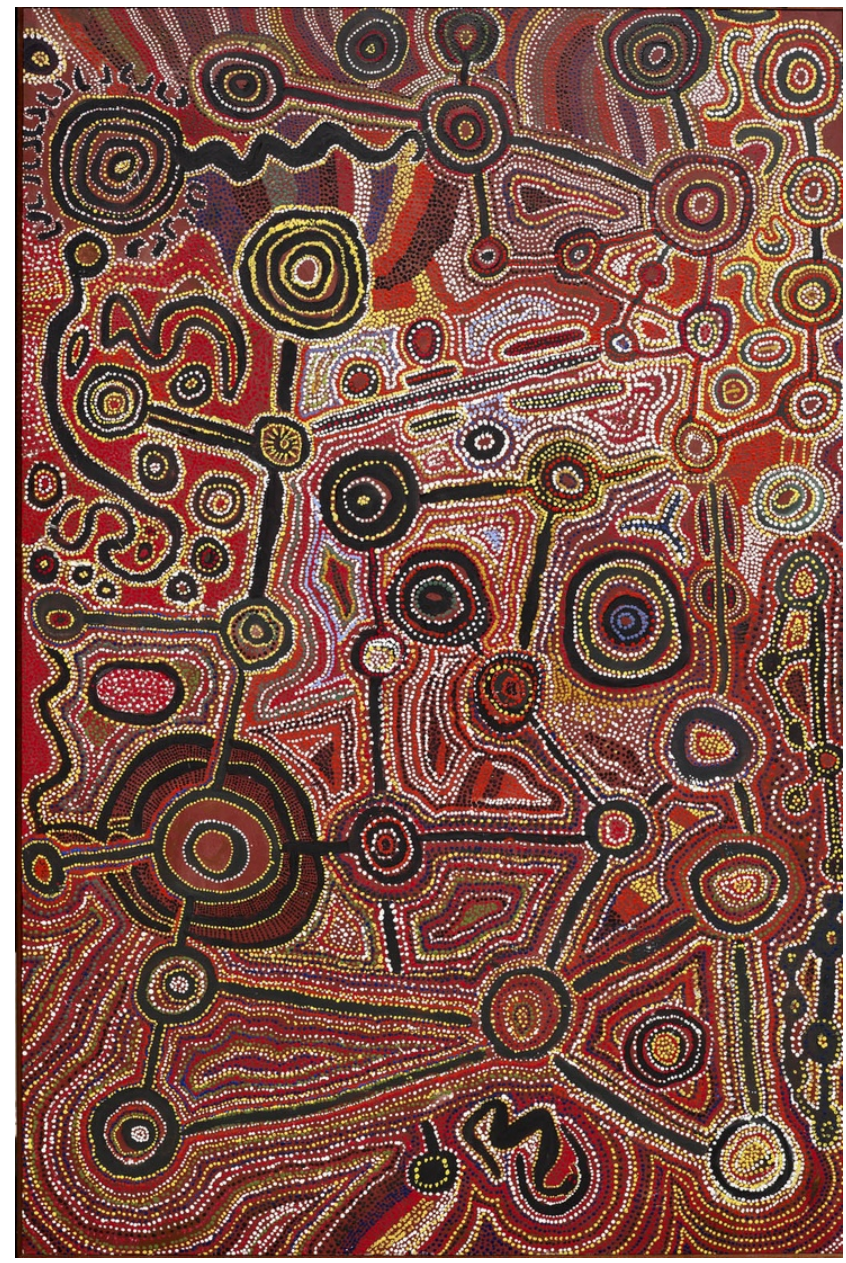

\section{Figure 6}

Kunmanara (Bill) Anderson, Kunmanara (Mark) Anderson, Byron Brooks, Kunmanara (Cyril) Brown, Fred Grant, Ned Grant, Lawrence Pennington, Ian Rictor, Lennard Walker, Untitled (Men's native title painting), 1998. Acrylic on canvas, $194.7 \mathrm{x}$ $127.9 \mathrm{~cm}$. Spinifex Arts Community Collection (photo: courtesy Spinifex Arts Project).

The men's native title painting (and its women's counterpart) documents traditional custodianship over lands from which Spinifex people had been dispossessed. It served as evidence in the native title claim, negotiated between 1992 and 1998, which secured the rights of Spinifex people as "traditional owners" of a 55,000 square kilometer homeland stretching across the Great Victoria Desert.

\footnotetext{
${ }^{17}$ The 1985 Royal Commission revealed Australia's distinction as the only postwar Western nation "where plutonium is dispersed without precise knowledge of how much is above and below the ground." Robert Milliken, No Conceivable Injury (Harmondsworth: Penguin, 1986), 238-243.
} 
Millennial land routes through the Woomera Rocket Range linked Spinifex homelands with the Ooldea soak hole, located three hundred and fifty kilometers to the southeast, at the edge of the Nullarbor Plain. As the area's sole permanent water source, Ooldea held enormous importance both as a crossroads of trade-related travel, and as a ceremonial center at the junction of paths traversed by ancestral beings in the infinite past made present in the Dreaming. Over a decade before atomic testing began at Woomera, ethnographer T.H. Johnson reported the significance of its "great north-south route" in the Proceedings of the Royal Geographical Society. The aridity of the lands bisected by the route meant that travel was seasonal, with water along some stretches available only from plant roots. ${ }^{18}$ While incapable of supporting permanent habitation, the inhospitable corridors linking sacred waterholes with homelands were irreducible components of the nomadic landscape: a model of territorial occupancy that Australian officials seemed incapable of comprehending.

The reliable soak hole at Ooldea also attracted the builders of the Australian transcontinental railway, completed in 1917. Ooldea served as a watering depot for steam engines, bringing indigenous nomads into contact with railway workers and travelers, with troubling consequences. Forced to wear clothing, encouraged by the presence of tourists to beg for offerings, and loathe to resume a life of desert scarcity, Aboriginal people at Ooldea embarked upon the trajectory that anthropologists called "detribalization." Concerned for the welfare of indigenous people increasingly dependent upon exogenous foods and goods, Daisy Bates, an Irish adventurer and philanthropist, set up camp at Ooldea in 1919. Established, in the words of historian Ray Acaster, "with the aim of helping the people she believed to be doomed to extinction to live out their final days with dignity," Bates' camp was the site of the first recorded reference to "Spinifex natives": the term used in a 1934 ethnographic study by Norman Tindale. ${ }^{19}$ Eight years later, anthropologists Ronald and Catherine Berndt observed:

Ooldea may be their "home camp" now, but their spiritual camps are those at which they were born "way back Spinifex" in their horde countries....[M]any of the sacred sites are far distant from Ooldea, and although the myths with their ancestral tracks are in country not now visited by the majority, each physiographical characteristic is remembered by the initiated men. ${ }^{20}$

In 1951, Tindale was shown a set of ritual objects at the Aboriginal mission that had succeeded Bates' camp. He recorded the origin of the artifacts as "the native place of Wayakula...in the vicinity of or west from the Lake Wyola of our maps." ${ }^{21}$ In correlating a Pitjatjantjara place name with a site in South Australia, Tindale had unwittingly revealed that Spinifex homelands extended one hundred and forty kilometers within the Woomera rocket testing range. ${ }^{22}$ His discovery, however, was of purely academic interest. Geopolitical imperatives impelled policies portraying Woomera as a wasteland where nuclear weapons

\footnotetext{
${ }^{18}$ Ray Acaster, "Worlds Apart: Atom Bombs and Traditional Land Use in South Australia," Limina 1 (1995): 57-58.

${ }^{19}$ Cane, Pila Nguru, 68.

${ }^{20}$ Ronald and Catherine Berndt, quoted in Acaster, "Worlds Apart," 60.

${ }^{21}$ Norman Tindale, quoted in Cane, Pila Nguru, 72.

22 David Nash, "Pila Nguru: The Spinifex People" (book review), Australian Aboriginal Studies 2 (2002): 97. Tindale's discovery calls into question Acaster's assertion that "there is no evidence to suggest that any Aboriginal people lived in the test areas at the time of weapons testing," a claim that is misleading given documentation of forced relocations just prior to the tests and concerted efforts by authorities to disseminate disinformation about test safety in order to preempt "the usual howl from the 'Ban the $\mathrm{H}$ Bomb' section of the community-Communist and otherwise," as stated by the Australian defense minister in a confidential memorandum (Milliken, No Conceivable Injury, 247).
} 
could be tested with "no conceivable injury to life, limb or property," as pledged by Australian Prime Minister Robert Menzies in $1953 .^{23}$

\section{Terra Nullius for the Atomic Age}

A final episode in the dispossession of Australia's first inhabitants unfolded halfway around the world during the late-1940s. With cold war hostilities escalating in Europe, the British Labour government no longer considered economic failure the nation's primary threat, but rather a potential war with the communist East. Rearmament became a priority, and the atomic bomb its weapon of choice. America's proving grounds in Nevada, with their access to US nuclear know-how, were the logical site for a British bomb test. However, information sharing on weapons development had ended along with World War II. The first successful Soviet atomic bomb test in 1949 provided humiliating proof that Great Britain had joined the ranks of postwar minor powers. Production of a British plutonium implosion device similar to those detonated above Hiroshima and Nagasaki progressed behind a shield of secrecy. Australia, which had signed a 1946 agreement for the cooperative development of a rockettesting range, would serve as the ground zero of last resort.

When British military authorities arrived in Australia to conduct their first test blast in the Monte Bello Islands, eight kilometers off the northwest coast, the only information source they had consulted about the Aboriginal population was the Encylopaedia Britannica. ${ }^{24}$ Responsibility for insuring the safety of natives, indigenous and otherwise, fell to Australian officials. The scope of their task expanded enormously when Menzies authorized atomic testing within the Woomera Range. The decision, taken without cabinet discussion or public debate, effectively condemned the traditional land route linking Ooldea to the Spinifex homelands. ${ }^{25}$ Coincidences aided and abetted the government decree. An extended drought had discouraged movement across the parched lands north of Ooldea over the course of the 1940s. And in 1952, a year before the first test detonation at Woomera, the United Aboriginal Mission at Ooldea closed, a victim of internal administrative bickering. In any case, the ritual soak had vanished into the sand, destroyed when railroad operators attempting to extract more water than the source could provide punctured its underground clay pan. Facing a forced move two hundred kilometers south to a Lutheran mission at Yalata, Ooldea's Aboriginal tenants wailed with anguish. Life on the grey soils of the Nullarbor Plain proved alienating; the red sands of the Spinifex exerted an irresistible pull. When the secretary of the Aboriginal Protection Board notified authorities at Woomera of his intention to allow unhappy interns to depart for the north, he received a brusque response: "Return of Abos to Ooldea would be undesirable in their own interests and could be a serious embarrassment to us." ${ }^{26}$ Two issues-nuclear ambition and public relations anxiety-would dominate Australian policies affecting Spinifex people for the next decade.

To patrol a 100,000 square kilometer area, the Weapons Research Establishment (WRE) at Woomera employed two men: Walter MacDougall, who had worked at missions in the Kimberley and central Australia, and Robert Macaulay, who had just received his degree in anthropology from the University of Sydney. It was a hopeless task, given its gargantuan

\footnotetext{
${ }^{23}$ Milliken, No Conceivable Injury, 58.

${ }^{24}$ Ibid., 94-95.

25 Ibid., 56.

${ }^{26}$ Ibid., 99-100
} 
scope and laughable resources (Fig. 7). MacDougall in particular felt profound empathy for the people he was hired to safeguard. The same cannot be said of the WRE, which in a classified document described his post as "an insurance policy ensuring that the Department does not come under public criticism for interfering with the tribal natives." ${ }^{27}$ In a 1955 Adelaide newspaper interview, MacDougall infuriated his employers by denouncing the weapons program's impact upon Aboriginal people as "contrary to the declaration of human rights in the United Nations charter." ${ }^{28}$ The accusation prompted the WRE to marginalize his position, creating further difficulties in fulfilling its duties. Torn by conflicting allegiances to his indigenous wards and the mandates of his job, MacDougall ultimately served the latter, "proving himself ready on a number of occasions to interfere substantially and persistently in Aboriginal lifestyles and wishes, when he believed Government policy and need so dictated," as stated in the report of the 1984 Royal Commission. ${ }^{29}$

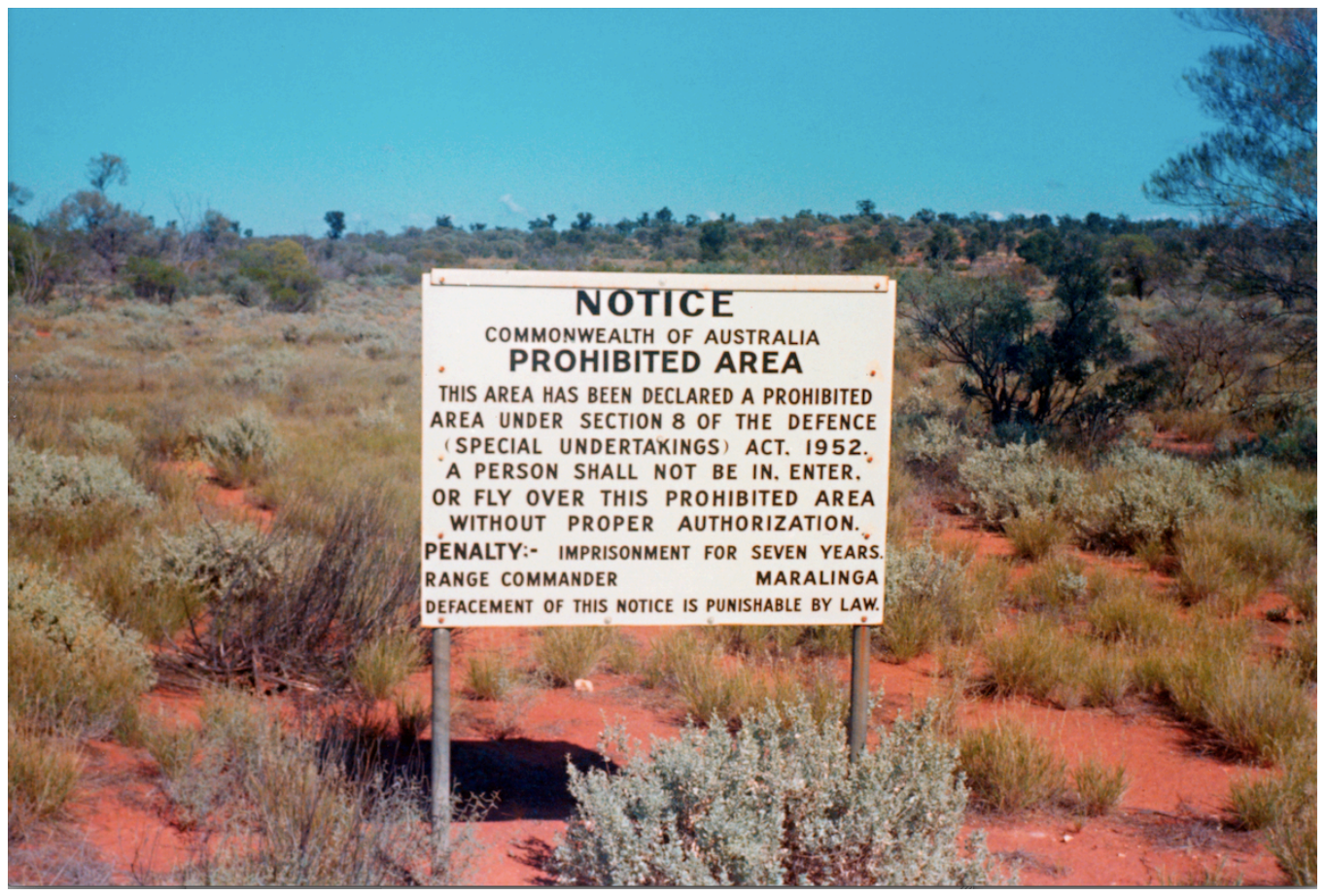

Figure 7

A signposted notice (in a language unintelligible to Aboriginal nomads) warns of seven years imprisonment for trespassing the bounds of the Maralinga nuclear test site at the Woomera Prohibited Area in South Australia. [source: Australian National Archive, Series: A6457 ("Photographs relating to atomic tests"), P042].

\footnotetext{
27 Ibid., 106.

${ }^{28}$ Ibid., 103.

${ }^{29}$ G.M. Eames and A.C. Collert, "Final Submission by Counsel on Behalf of Aboriginal Organizations and Individuals to the Royal Commission into British Nuclear Tests in Australia," quoted in Maggie Brady, "The Politics of Space and Mobility: Controlling the Ooldea/Yalata Aborigines, 1952-1982," Aboriginal History 23 (1999): 4.
} 
Confronted with the challenge of controlling hundreds of highly mobile desert people, MacDougall developed a three-pronged strategy, identified by historian Maggie Brady as withholding rations, intercepting movement, and manipulating indigenous beliefs. The first two are fairly self-explanatory; the last had consequences perhaps more insidious than MacDougall ever imagined. To curtail nomadic travel and alienate Aboriginals from familiar lands, he revised indigenous myths, in his words: "using their own beliefs and fears of invisible spirits and invisible avengers [to] convince them that the area is no longer safe for them." ${ }^{30}$ MacDougall intervened when, in May 1957, workers at Woomera discovered an Aboriginal family of four camped at Piling waterhole: a site associated with ritual ceremony and desert survival, and located five kilometers from the Marcoo bomb crater blasted six months earlier. After technicians decontaminated the family and shot their dogs, MacDougall told the adults that they had stumbled onto the site of a taboo "whitefella" corroboree. They were sworn to secrecy before being shipped off to Yalata. ${ }^{31}$

Far more destructive was MacDougall's manipulation of Aboriginal myths regarding venomous wanampi serpents and the evil spirits called mamu. He informed nomads encountered in the desert and interned in missions that the bombs had released a deadly mamu poison across the Woomera landscape. At Yalata, where according to Brady "radioactivity became known universally...as the 'poison,'" interviews in the mid-1980s documented a continued belief that wanampi ran rampant at the weapons testing site, making travel there a fatal proposition. ${ }^{32}$ In formulating his warning in the tenets of another worldview, MacDougall added an ontological contaminant to the radioactive fallout polluting their homelands. During the ensuing exodus, some refugees traveling died of thirst because, fearing "the poison" pervading ancestral lands, they refused to venture away from the safety of familiar tracks to obtain water sequestered in known locations beneath the desert surface. At the Royal Commission hearings, an Aboriginal elder testified: "Piling [rock hole] no good, kapi [water] no good. Wiluna rock-hole, we can't trust him, we can't trust water near Maralinga.... The bomb finished it." ${ }^{33}$

It is, of course, possible that nomads eventually would have framed the poisoning of country in native terms. In any case, especially when writing for a non-Aboriginal audience, it is impossible to overstate the cataclysm that this confluence of technological and supernatural toxins represented to Spinifex people. Among Aboriginal nomads, personal identity from ritual rights to land tenure literally was defined by one's umbilical relationship to country-that is, by the specific place where an infant shed its umbilical cord. The geographic site of conception determined which Tjukurpa, or ancestral Dreamings, entered a developing life. ${ }^{34}$ At the world's first atomic detonation in the New Mexico desert in 1945, a line from an ancient Hindu text, the Bhagavad-Gita, occurred to physicist Robert Oppenheimer: "Now I am become Death, the destroyer of worlds." It summarized perfectly the impact nuclear testing had upon an indigenous landscape saturated with meaning.

\footnotetext{
${ }^{30}$ Brady, "The Politics of Space and Mobility," 6.

${ }^{31}$ Acaster, "Worlds Apart," 64; Gara, "Walter MacDougall," 2.

32 Brady, "The Politics of Space and Mobility," 6.

33 Scott Cane, "Sun and Shadow," in Spinifex: People of the Sun and Shadow (Bentley: John Curtin University, 2012), 21 Evidence given at the Royal Commission into the British Nuclear Tests in Australia, quoted in Acaster, "Worlds Apart," 64.

${ }^{34}$ Individual custodianship of a desert site and its attendant Dreamings is determined among nomads by their location in the landscape at the moment their umbilical cord detaches in infancy. For a discussion of land tenure and identity among Spinifex people, see Cane, Pila Nguru, 64-68.
} 
MacDougall focused his efforts upon nomads at Yalata, having dismissed "the possibility of Aboriginal people entering the danger areas from the west, from the spinifex," as historian Tom Gara notes. However, in 1956-the year that saw the first of seven atomic test detonations at Maralinga-MacDougall happened upon fifty-four nomads near the Kulkapin rock hole, a collection point from which missionaries from Cundeelee evacuated desert dwellers. None had ever encountered a non-indigenous person before. A sweep made in 1959 found thirty-four people living beside Shell Lakes, more than half of whom were making hunting trips to the east, many crossing into the weapons testing area. MacDougall informed authorities at Woomera: "There are natives living on the fringe of the Maralinga Prohibited Zone and in the Zone itself. Natives travel through the area and reach a point at least halfway from the border to the Forward Area [the nuclear testing grounds]." ${ }^{\prime 35}$ In the same year, Carlene Anderson arrived in Cundeelee, the Western Australian mission that collected many of the Spinifex exiles. She had been with a large group of her people at the Ilkurlka rock hole when intruders arrived in the company of a clothed Aboriginal guide. "There were two white men with him who told us to move on," Anderson recalled decades later. The group, given clothing, walked on to rock holes at Pauipya and Iltun where a missionary in a jeep approached. "Everyone was looking down. We were ashamed." He told them to proceed to a collection point from which they were evacuated. "We were frightened about the bomb," Anderson confessed, "and didn't go back." ${ }^{36}$ In 1960, with Jerome Anderson as guide, patrols of the Kulkapin, Pirapi and Pitjrinya soak holes found fifty-one desert residents. In the same year, a group of nomads encountered by a constable at Serpentine Lake, bordering the prohibited zone, "said they heard the atomic bomb at Maralinga and were very frightened." ${ }^{37}$ Told by WRE officials and indigenous guides that the land had been "poisoned" by nuclear testing, Spinifex people left their homelands for mission life in ever-greater numbers. Those who remained felt increasingly isolated and insecure in the desert, having lost the youths needed to parent new generations and the elders whose sacred knowledge provided protection in a landscape teeming with spiritual forces. As Acaster notes, the diaspora from lands that "the bomb finished," as dispossessed inhabitants believed, culminated a "process of lifestyle disintegration" that had begun generations earlier. ${ }^{38}$

\section{Homeward Bound}

For Spinifex people consigned to missions, nomadic mobility took new forms. At Yalata, another manipulation of indigenous tradition curtailed the impulse to wander, particularly northward to Ooldea and the test area beyond. Responding to attempts by indigenous residents to leave the mission, MacDougall devised a plan to keep Aboriginals on the move within its boundaries instead. Lutheran missionaries, anxious to remain in the good graces of Woomera officials tracking the status of new interns, established multiple campsites on mission grounds. Twenty years later, anthropologist Sally White marveled at Yalata's unique pattern of internal migration, in which residents decamped several times a year to a different part of the reserve, never realizing that this nomadic tradition had been invented in the 1950 s to keep an interned population away from the weapons range. "They were penned in,"

\footnotetext{
35 Gara, "Walter MacDougall," 2.

${ }^{36}$ Cane, Pila Nguru, 183.

37 Ibid., 177, 180.

${ }^{38}$ Acaster, "Worlds Apart," 65.
} 
Maggie Brady observed in 1999, "not by fences, but by the need for water supplies, their dependence on European rations, and the surveillance of the missionaries." ${ }^{139}$

Cundeelee mission, a government ration depot and the repository for many nomads removed from Spinifex homelands, also reprised older patterns of movement. Located two hundred kilometers east of Kalgoorlie in Western Australia, Cundeelee inadvertently preserved indigenous culture due to a meager level of subsidy. Insufficient food rations impelled residents to maintain hunting and foraging skills. Inadequate shelter encouraged the construction of traditional windbreaks. Reliance on firewood for fuel compelled nomadic residency patterns as resources at a given site became exhausted. To supplement the pittance earned through the mission business of harvesting sandalwood, men at Cundeelee sold boomerangs crafted with stone tools, and were declared the world's last users of this Paleolithic technology by American anthropologist Brian Hayden. After a stinging federal indictment of the settlement facilities, in the mid-1970s the Australian Evangelical Mission withdrew, turning Cundeelee over to Department of Aboriginal Affairs (DAA) administrators. They, in turn, closed the settlement within a few years due to deficiencies in its water supply, spreading dismay among wards of state subjected to yet another forced removal. ${ }^{40}$ Residents were relocated to Coonana, a former pastoral station transformed into a multi-million dollar DAA settlement, and again situated in a landscape completely alien to the community it served.

The multiple relocations of Spinifex exiles occurred just as Aboriginal Australians elsewhere were mobilizing to reclaim their indigenous heritage and homelands. In 1972, a collective comprised of different desert peoples resettled at the federally operated Papunya community in the Northern Territory established Papunya Tula Artists Pty. Ltd., an Aboriginal owned and operated artists' cooperative. On the heels of a cultural renaissance that used industrially produced paints and surfaces to express ancestral narratives of territorial custodianship, the Northern Territory's 1976 Aboriginal Land Rights Act provided legal recourse for indigenous Australians wishing to claim traditional ownership of country through evidence of longstanding association. Across the desert during the course of the 1970s, thousands of Aboriginal people, encouraged by new government policies of selfdetermination, abandoned government relocation settlements (along with their underlying rationale of assimilation) to return "back to country" in an epoch-defining outstation movement. For Spinifex people, a return to ancestral lands had life-or-death implications. While youths living in government or mission settlements may have enjoyed their proximity to mining towns, elders feared the disastrous consequences, particularly in regard to alcohol consumption. In a 1987 interview, senior spokesman Mark Anderson explained: "A mamu (evil spirit) got hold of our people at Cundeelee and led them into town to die. We were drinking." Reginald Anderson concurred: "We hung around Kalgoorlie. We were drinking and many of us passed away.... We lost our country. We lost our country." Pointing to his head, he added: "We kept it in here." ${ }^{41}$ (Fig. 8)

\footnotetext{
${ }^{39}$ Brady, "The Politics of Space and Mobility," 8-9. Brady's account contains this remarkable footnote: "Lutherans of the time believed that Aborigines were 'communists' in that they had no individual property ownership."

${ }^{40}$ Cane, Pila Nguru, 190-96.

41 "The 'lost tribe' was right at home," 6.
} 


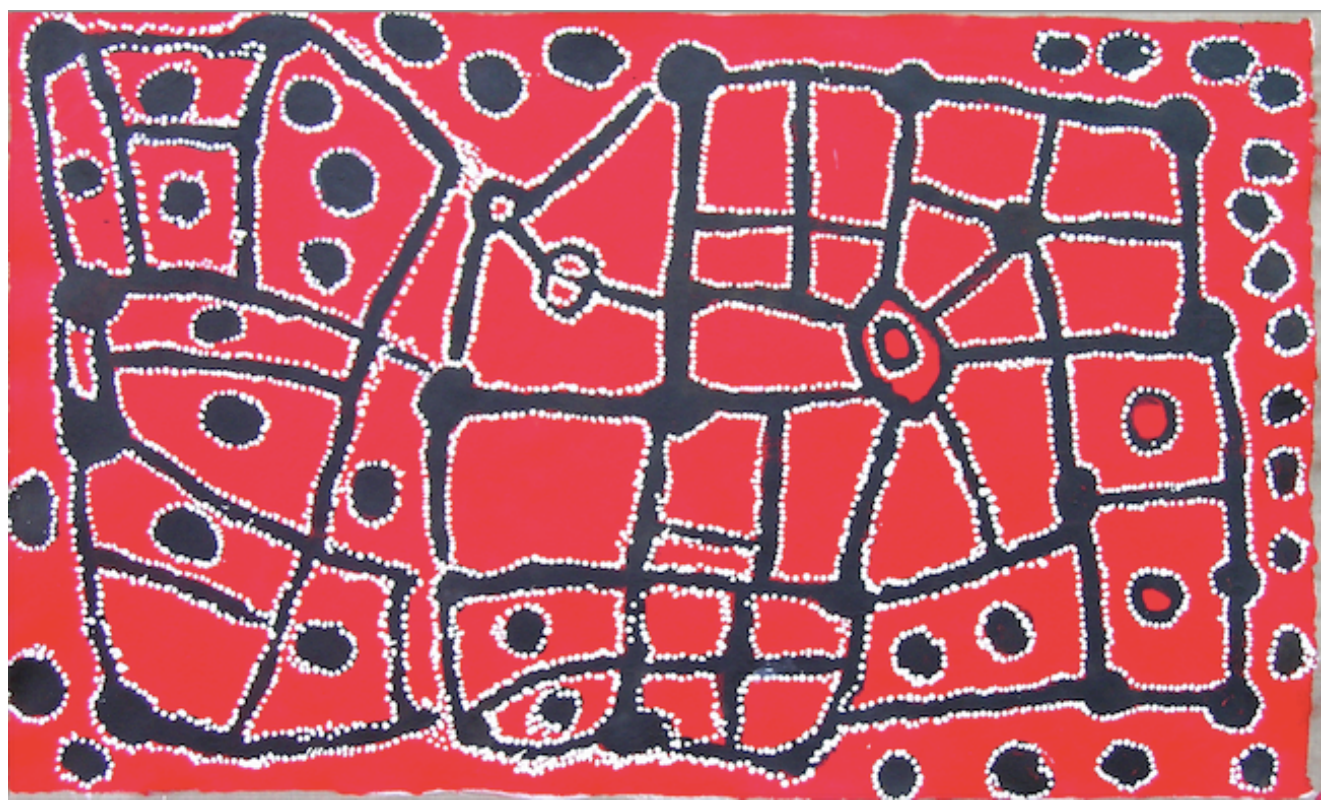

Figure 8

Kunmanara (Mark) Anderson and Kunmanara (Ester) Rice, Paltju, 2005. Acrylic on linen, $140 \times 83 \mathrm{~cm}$. Private collection (photo: courtesy Spinifex Arts Project).

Centered on Paltju, an important water soak in the western portion of Spinifex country, this painting represents an expanse of approximately one hundred square kilometers. As people moved across this area, extensive and precise knowledge about the location and reliability of water sources was essential. Anderson and Rice, a husband and wife team, depict an array of water-retaining rock hole formations bounded by numerous small soaks found in the surrounding sandhill terrain. The artists have included the watering sites of Paramanti, Pakar, Kaltjumurtja, Tjaning, Tjampirngka, Umpun Kurli, Tjirukuna, Putumuturatjara, Waru, Tjuntjun, Tarantjara, Wanupi, Ilkurlka, Ilkurlka-mama, Wakarnurma, Mamutu, Tjata, Tjata-pulka, and Paltju.

Elders fomented an exodus from Cundeelee. In 1983, DAA officials relented and acquired a sixteen thousand acre lease at the Yakatunya rock hole, a site charged with cultural significance, unlike Coonana. With a compensation award from the Royal Commission, the community built their road back home. Elder Simon Hogan, a "walking encyclopedia" of indigenous tradition, trekked three hundred kilometers from Yakatunya to the northern margin of Spinifex country, blazing a path from rock hole to rock hole as his son followed behind driving a road grader. ${ }^{42}$ The new route permitted access to what would become the most remote outstation settlement in Australia. Located in the southeastern corner of the Spinifex homelands, Tjuntjunjara comprised a group of canvas windbreaks arrayed around permanent structures including a store, clinic, community office and school. Life there quickly conformed to seasonal rhythms, with sojourns for ceremonial "business," and cross-country travel to hunt, harvest medicinal plants, and collect the ochre, feathers and stones used in ceremonies.

The move to Tjuntjunjara brought full circle the Spinifex people's "long days," as they call their recent history. Their cold war peregrinations ended with a return to country while it was still possible, guided by elders with living memories of the homeland and its spiritual

${ }^{42}$ Cane, Pila Nguru, 196-98. 
forces. Elders also assumed the functions of a political and artistic avant-garde. In 1992, a landmark decision by the Australian High Court to recognize native title in the Mabo $v$. Queensland suit overturned the legal doctrine of terra nullius. Within a year, Spinifex people launched their own claim process. Their first visit to the National Native Title Tribunal marked the first time the body had met directly with Aboriginal petitioners, rather than their legal and anthropological representatives. Spinifex seniors disclosed their intentions to mining company executives, securing an agreement to withdraw all mineral exploration applications. Talks with Aboriginal kinsmen to the north and east of Spinifex country yielded an agreement on territorial boundaries, permitting formal submission of a native title application in October $1994 .^{43}$

In 1997, with their native title application well underway, community members whose birthplace in Spinifex Country would constitute grounds for the claim of traditional ownership began painting. The new practice took the encampment at Tjuntjuntjara by storm, with up to a third of its residents working first on cardboard, then on canvas boards, and finally on canvas. Discussions of places of origin and their associated Tjukurpa preoccupied the new artists as they worked through the day and often into the night. ${ }^{44}$ The resulting series of small experimental works, now in the Spinifex Arts Community Collection under the denomination of "government paintings," provided the skills necessary to produce a collaborative painting that would document the responsibilities and embodied knowledge implicit in the native title claim. With assistance from community arts coordinator Louise Allerton, elders created a map of birthplaces as preparation for a large canvas that would serve as legal evidence of traditional land ownership. The process and its proposed product, an artifact crafted explicitly for the public disclosure of the birthrights associated with sacred places-some ascribed with extreme ontological peril-had no historical precedent for Spinifex people or their culture.

Negotiations soon revealed that men and women would not be able to share their ritual knowledge on the same collective canvas: neither wanted the other group present while marking out gender-specific secrets. ${ }^{45}$ The pair of large untitled compositions that emerged from group consultation, enshrined as the women's and men's native title paintings of 1998, established the guidelines for Spinifex painting as a contemporary practice, recently glossed by curators Ross Chadwick, John Cruthers, and Carly Lane as follows: "unless married, men and women usually work separately; each gender owns and paints their own ancestral narratives; and within that gender division, collaboration is encouraged-indeed, it is an essential element of practice. ${ }^{\prime 46}$ The first two collective paintings were unveiled at the signing of a native title framework agreement in July 1998 at Miramiratjara, an oasis in a remote northeastern corner of Spinifex country, and a site so charged with metaphysical dangers that elders entered in advance to introduce the place to its new visitors. When he arrived by helicopter, the Premier of Western Australia, Richard Court, was only the third white Australian to ever see the sacred water source. ${ }^{47}$ The event encapsulated a tension permeating Spinifex painting: a representational practice that encodes traditionally guarded

\footnotetext{
43 Cane, "Sun and Shadow," 21-22.

${ }^{44}$ Luise Allerton, "Recollections of the Spinifex Arts Project," in Spinifex: People of the Sun and Shadow (Bentley: John Curtin University, 2012), 26.

45 Ibid., 28.

${ }^{46}$ Ross Chadwick, John Cruthers, and Carly Lane, "The Exhibition," in Spinifex: People of the Sun and Shadow (Bentley: John Curtin University, 2012), 12.

47 Cane, "Sun and Shadow," 22.
} 
knowledge on permanent materials created for broad circulation (rather than as an ephemeral pattern, destined for erasure after ritual use, on a surface of sand or skin) in order to make ancestral land tenure publically and politically explicit.

A market for Spinifex works emerged between 1999 and 2000 when a traveling exhibition featuring the native title and government paintings toured half a dozen Australian cities. Coincident with a moment of ebullient expansion in Aboriginal art sales, the debut of a new cohort of indigenous painters excited gallery owners as well as the artists themselves, who eagerly embraced the affirmation of their traditional ownership of country and its cosmologies, and the novel offer of remuneration for documenting their custodial authority. ${ }^{48}$ As the anthropologist John Carty points out: "Painting, Spinifex style, is a form of evidence." ${ }^{\prime 49}$ The Spinifex Arts Project, with its inherently political goals, anteceded the commercial market for its aesthetic production, which has consequently charted a somewhat different course than that of other Western Desert "schools." With public disclosure of the carefully guarded stories and sites of ancestral Dreamings made a priority by the native title process, the imperative to render visible the unspeakable continues to dominate Spinifex painting. A vivid iconography depicting the footprints, pathways, and animal silhouettes of specific Tjukurpa, purged from the output of more circumspect Aboriginal art collectives, remains a feature of Spinifex works. ${ }^{50}$ While making collective paintings, artists often sing the songlines being committed to canvas (Fig. 9 and 10). ${ }^{51}$ Their ability to depict Dreaming narratives while safeguarding restricted content may be related to the exogenous materials of contemporary painting. When Allerton asked Spinifex men why they tended to mark out the overall design of paintings in red, wondering if the choice of color was related to the ceremonial uses of natural ochre, their reaction quickly let her know that the topic "was an absolute no-go zone." Since Spinifex artists, unlike contemporaries farther north, have avoided painting with natural ochres, it is possible, as Allerton suggests, that modern materials like synthetic acrylic paints insulate aesthetic production from ritual ceremony, making the results "safe" for viewing by the uninitiated. ${ }^{52}$

\footnotetext{
48 Allerton, "Recollections of the Spinifex Arts Project," 30. On the growth and nature of the market for Aboriginal contemporary art, see: Meaghan Wilson-Anastasios, "Joining the Dots: Analysing the Sustainability of the Australian Aboriginal Art Market," Diogenes 58 (2011): 22-34.

49 John Carty, "Seeing the Desert for the Trees: The Gift of Spinifex Art," in Spinifex: People of the Sun and Shadow (Bentley: John Curtin University, 2012), 43.

${ }^{50}$ In particular, the Punu ngura project initiated by Hector Burton and a group of Amata men at Tjala Arts represented an attempt among senior male artists to limit the acceptable subject matter for painting to representations of trees. Maintaining that Aboriginal contemporary art had exposed too much sacrosanct content in return for cash, Burton and his allies used trees to "build a fence" around their culture. His allegations reached their flashpoint in the delayed opening of the 2014 Ngintaka (Seven Sisters Songline) exhibition at the South Australian Museum in Adelaide. Burton's accusations are presented in Nicolas Rothwell, "Songlines project sparks indigenous culture war," The Australian, March 22, 2014. A dissenting opinion is presented by Bob Gosford in "For shame, Nicolas Rothwell," Crikey, March 31, 2014. Accessed February 21, 2105, http://blogs.crikey.com.au/northern/2014/03/31/why-nicolas-rothwell-should-be-ashamed/.

51 Carty, "Seeing the desert for the trees," 42.

52 Allerton, "Recollections of the Spinifex Arts Project," 32.
} 


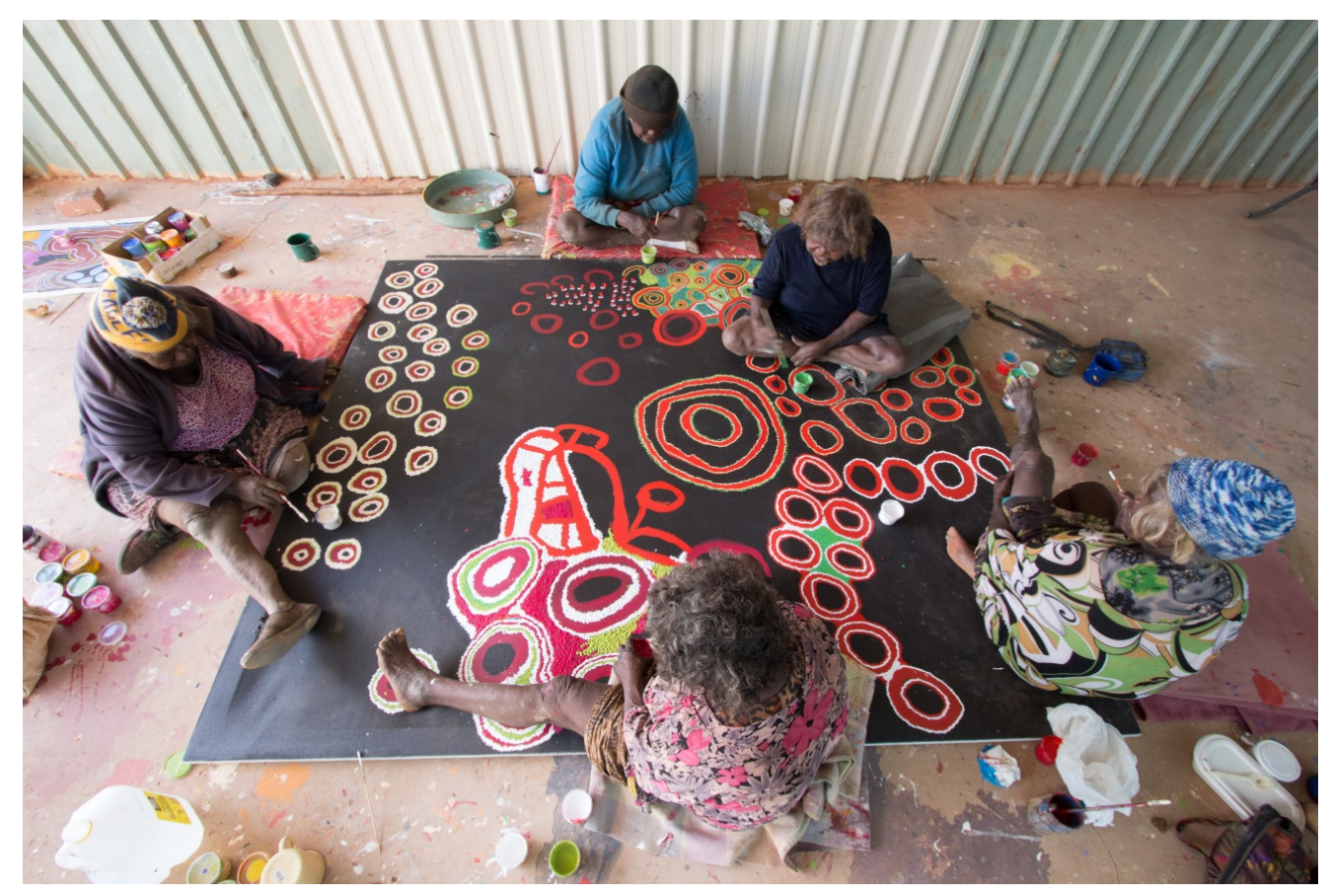

\section{Figure 9}

Spinifex Arts Project members Kunmanara (Anne Ngantiri) Hogan, Tjaruwa Woods, Yarangka Thomas, Ngalpingka Simms, and Myrtle Pennington painting the womens' collective canvas Kungkarangkalpa, featured in the 2015 British Museum exhibition Indigenous Australia: Enduring Civilization. (photo: courtesy of the Spinifex Arts Project and Redot Gallery).

The custodianship of ancestral country central to Spinifex artists and their work prompts the art historian Ian McLean to characterize their oeuvre as "neo-traditional." This is not to say anti-modern: the processes of modernity that have touched indigenous Australian lives have been used as opportunities to revive older relationships with the land and its songlines. "Neo-traditionalism is not a return to how things were (i.e. traditionalism), or a nostalgia for what once was (i.e. conservatism)," McLean writes, "but the use of traditions to reinvigorate and give direction to contemporary life." ${ }^{53}$ One of these is inherent in the use of the term Anagu tjuta pila nguru, or "people from the land of the spinifex": an elective identity that implicitly rejects the Western ethnographic practice of identifying Australian Aboriginal people not by territory, but by language group; for example, Pitjatjantjara, Arrernte, Lurtja, Warlpiri, etc. The embrace of tradition is also visible in the visual language to which Spinifex artists adhere. While the medium of acrylic paint on canvas or linen is contemporary, as is the vibrant palette that the Spinifex women adopted right from the start of their career as painters, the iconography that they employ remains consistent with that long used throughout the Western Desert to communicate by drawing in sand. Curators and collectors use terms like "old worldliness" or "unmistakably Spinifex" to describe the artists"

\footnotetext{
${ }^{53}$ Ian McLean, "Spinifex Art: The Aesthetic Politics of Neo-Traditionalism," in Tupun Nguranguru: People of the Sandhill Country (Melbourne: Vivien Anderson Gallery, 2012), 5.
} 
loyalty to formal legacies no longer in fashion at the top rung of the Aboriginal contemporary art market. ${ }^{54}$ Angelina Tjaruwa Woods, the youngest and most experimental of first generation Spinifex artists, has come closest to the abstraction highly prized in the marketplace. She created a cluster of paintings in 2009 and 2010 that explored the technique of dissolving traditional iconography in clotted pools of dots that alternately obscured and revealed the familiar forms of concentric rock holes and their connecting pathways. The most radical of these works, Kamanti (Fig. 2), now in The Lepley Collection, proved irresistible to collectors: "I could have sold that painting five times," recalls gallery manager Mirri Leven. ${ }^{55}$ Shortly after this experiment with an unorthodox mode of expression, Woods' work moved back toward clarity of form, featuring legible symbols immured in fields of color. Her most recent compositions are consistent with the distaste for expressionistic dotting asserted by her senior peers. ${ }^{56}$ Just as with other works of contemporary art, Spinifex paintings are now produced as a commodity; however, their neotraditional representational imperative remains potent enough to resist compromise by market influences.

With respect to their own community, artists paint homeland narratives to allow family who may not have visited their country to view and understand its Tjukurpa through its visual iconography, according to Richard Brookes, a senior Spinifex traditional landowner. ${ }^{57}$ The indigenous didactic function of a process that also yields works of art for external consumption establishes the cultural limits of the critique of the market for nostalgic "primitivism" made by the Aboriginal artist and activist Richard Bell in 2003, now known as Bell's Theorem: "Aboriginal Art - It's a White Thing. ${ }^{\prime 58}$ On the contrary, in adopting an exogenous art medium and its materials, Spinifex elders, the bearers and guardians of cultural tradition, have elected to transform it in ways of their choosing. In particular, contemporary art has fundamentally altered traditional attitudes about the disposition of objects belonging to the deceased. Among Western Desert peoples, the elimination of all traces of the departed by burning former possessions, even wiping way footprints, accompanies an intense early phase of mourning. The senior painter Lennard Walker, however, affirms the revolutionary transformation initiated by contemporary creative practice: "When I die my paintings will keep going. They will stay around forever and keep telling the story of Kamanti, where I was born. ${ }^{\prime 59}$ The ability to fashion permanent representations of an individual's connection to place and its Tjukurpa has not only imparted a sense of pride, but also inaugurated a profound shift in the temporality inherent in artifacts of Aboriginal material culture intended for unrestricted viewing in everyday settings.

\footnotetext{
${ }^{54}$ Allerton, "Recollections of the Spinifex Arts Project," 30, 33.

55 Mirri Leven, conversation with author, Bondi Beach, July 2013.

${ }^{56}$ Carty, "Seeing the desert for the trees," 50.

57 Louise Allerton, "Walka Tjukurpa Wirutjara: Painting Good Stories," in Tupun Nguranguru: People of the Sandhill Country (Melbourne: Vivien Anderson Gallery, 2012), 3.

58 The aphorism appears on Bell's painting Scientia E Metaphysica (Bell's Theorem), which won the 2003 Telstra National Aboriginal \& Torres Strait Islander Art Award.

${ }^{59}$ Lennard Walker quoted in Allerton, "Walka Tjukurpa Wirutjara: Painting Good Stories," 3.
} 


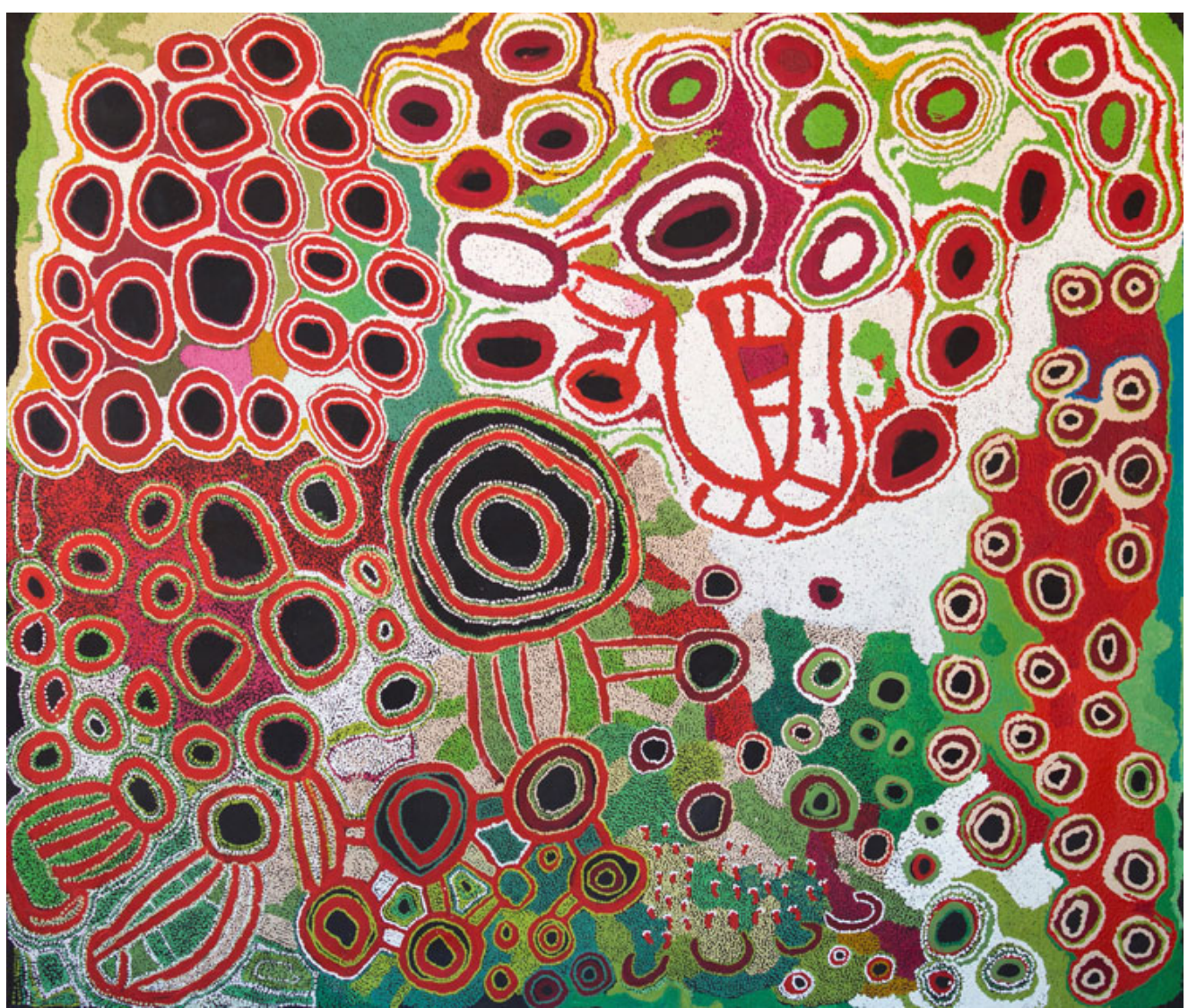

Figure 10

Kunmanara (Anne Ngantiri) Hogan, Tjaruwa Woods, Yarangka Thomas, Estelle Hogan, Ngalpingka Simms and Myrtle Pennington, Kungkarangkalpa, 2013, acrylic on linen, $197 \times 223 \mathrm{~cm}$. British Museum (photo: courtesy Spinifex Arts Project and Redot Gallery).

Six senior Spinifex women have painted country associated with their birthplaces as well as the Kungkarangkalpa (Seven Sisters) songline. This is an epic Tjukurpa which covers the vast tracts of land in the Spinifex claim area depicted here (although the Seven Sisters songline in fact extends much further afield). While elements of this story are highly sacred and secret, covering aspects of sexual life and women's rights of passage, the outline of the story is public knowledge. It chronicles the travels of the women through country as they attempt to avoid the unwanted attention of a lustful man named Nyiiru. These creation beings left existing land forms in the wake of their travels and adventures; the Seven Sisters story also accounts for the formation of the Pleiades constellation in the southern hemisphere's night sky.

Spinifex paintings, as McLean observes, are "not just documents of ownership but also the pretext for reoccupying county and in a literal sense refiguring it for the modern revival of traditional cosmology." ${ }^{\prime 60}$ Today, Toyota Land Cruisers return the artists to country for

${ }^{60}$ McLean, "Spinifex Art," 5. 
plein air painting camps where, for example, a group of senior women might stake out a spot on a sand dune at a salt lake to sing and paint its Seven Sisters Dreaming into life. ${ }^{61}$ The vital bond with country, like its expression in art, has endured the fluctuations of political regimes and art markets because it is nothing less than the lived truth of Spinifex people. One of its most eloquent spokesmen remains "old man" Glen Rictor, who in 1986, after ending his desert isolation, explained his relationship to the land and its sacred law to a reporter from the Sydney Morning Herald: "It was good out there. Good country. Always water out there... I looked after my country." Without its people, the land had been left "an orphan," roaming and lost "without parents to go to." With resettlement at Tjuntjuntjara and the resumption of custodial rituals, the land had recovered its caretakers, and the caretakers their lifeworld. A newspaper account of the elder Rictor's first visit to his homeland after abandoning nomadic life for the company of Spinifex kin conveys the sense of reunion with country for one of its custodians: "He galloped up the sandhills with ease and began to exude a happiness that his people had never seen before." ${ }^{\prime 2}$

\section{Acknowledgements:}

The author owes a debt of gratitude to Ian Baird, Amanda Dent, Robyn and Mattias Kelch, Fred Myers, and Terry Smith for their comments and corrections; and to the Redot Gallery and the Spinifex Arts Project for the generous provision of illustration images.

\footnotetext{
${ }^{61}$ Allerton, "Recollections of the Spinifex Arts Project," 34
}

62 "The 'lost tribe' was right at home," 6. 
(cc) $\mathrm{EY}$

New articles in this journal are licensed under a Creative Commons Attribution 4.0 United States License.

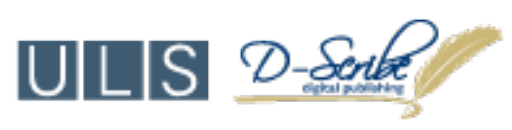

This journal is operated by the University Library System of the University of Pittsburgh as part of its D-Scribe Digital Publishing Program, and is co-sponsored by the University of Pittsburgh Press. 